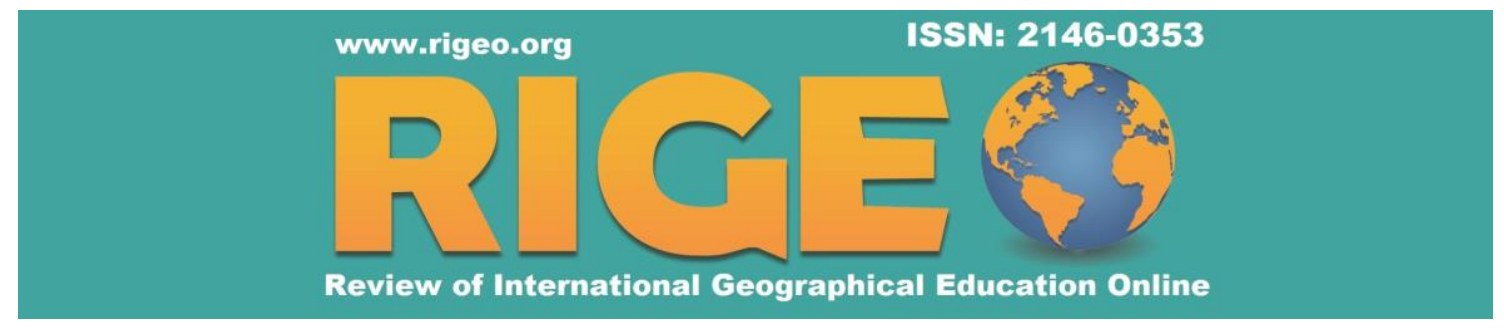

Review of International Geographical Education Online

(C)IGEO Volume 9, Number 3, Winter 2019

Review Article

Copyright $\odot$ RIGEO 2019

To cite this article: Larsen, T.B.; Harrington, J., Jr. (2019). Learning Progressions, Paradigms, and Geographic Thinking in the Anthropocene. Review of International Geographical Education Online (RIGEO), 9(3), 542-556. Retrieved from http://www.rigeo.org/vol9no3/Number3Winter/RIGEO-V9-N3-3.pdf

DOI: 10.33403 /rigeo.561562

Submitted: May 7, 2019 Revised: September 5, 2019 Accepted: November 29, 2019

\title{
Learning Progressions, Paradigms, and Geographic Thinking in the Anthropocene*
}

\author{
Thomas Barclay LARSEN ${ }^{1}$ \\ Texas State University, Texas, USA \\ John HARRINGTON, Jr. ${ }^{2}$ \\ Independent Scholar, Washington, USA
}

\begin{abstract}
Learning progression research has the capability to connect thinking in the education sciences and geography. Learning progressions provide a map of the various pathways that students take to master a topic. The aim of this paper is to illustrate significant conceptual ties between learning progressions and disciplinary geography. Two construct paradigms overlap to form an entryway between educational and geographic thought: constructivism from education and possibilism within geography. The learning progression method can form a bridge between the two paradigms. Learning progression research in geography depends on being able to answer two questions. First, which geographic concepts should be tracked? Given the ongoing changes in global human-environmental systems, priority could be dedicated to the topics that stimulate synthesis thinking about the human-environment relationship in the Anthropocene, or "Age of Humans." Second, how should geographers track advancement in learning about human-environment concepts? Learning progression research provides a method to document multiple aspects of advancement in student learning. But, geographic learning does not exist solely in the confines of the classroom. Furthermore, school districts vary in the amount and quality of geography that they allow. New understandings would come from a mixed-methods approach that addresses geographic understandings by the lifelong learner in the context of both formal and informal geography education.
\end{abstract}

\section{Keywords}

Learning Progressions, Paradigms, Geographic Thought, Possibilism, Anthropocene

*This paper was delivered in Washington, DC during the National Center for Research in Geography Education's (NCRGE) 2019 AAG Annual Meeting Symposium on Transformative Research. The session was titled "Paradigms and Milestones in Geography Education: Looking Back, Looking Forward."

${ }^{1}$ Corresponding Author; Department of Geography, Texas State University, 601 University Drive, San Marcos, TX 78666-4684, Phone: (512)-245-1823, tblarsen [at] txstate.edu, ORCID: 0000-0002-5059-1780

2Independent Scholar, PO Box 411, 19 School St., Bay Center, Washington, USA 98527; jharrin [at] ksu.edu . ORCID: 00000003-4066-0735

(C) Review of International Geographical Education Online RIGEO 2019 ISSN: 2146-0353 
Learning is complicated because it can occur laterally, it can advance, or it can digress and derail. The learning progression method is a dynamic research process that tracks the myriad journeys of student learning in a subject (NAS, 2007). For example, students are likely to take different paths to become more sophisticated in thinking about human-environment interaction. One student might be able to connect with the societal processes involved whereas another may identify with a recognized environmental perception, impact, or hazard.

Learning progression researchers use qualitative and quantitative approaches to examine how students advance in their understanding (Gunckel, Mohan et al., 2012; Solem, Huynh, and Boehm, 2015). A significant challenge is accounting for the multitude of student backgrounds, perspectives, and educational contexts (Black, Wilson, and Yao, 2011; Furtak, Morrison, and Kroog, 2014; Hammer and Sikorski, 2015). As a result, research on a specific learning progression may take a decade to fully mature. The commentary that follows points out that learning progression research emerged from paradigms in education but has translatable qualities for paradigms in geographic thought. Learning progression research is establishing stronger intellectual ties between education and geography (Larsen and Harrington, Jr., $2017,2018 b$ b. This paper presents the ways in which the two realms already coalesce, and why a stronger relationship would prove beneficial for students as they confront emerging socio-ecological challenges in the Anthropocene (i.e., the "Age of Humans").

Formally, learning progression research began in the early 2000s addressing math and science education (Huynh, Solem, and Bednarz, 2015). Some would argue that initial learning progression efforts occurred decades before, with the work on scaffolding (Plumert and Nichols-Whitehead, 1996; Reiser, 2004; Foster and Hund, 2012; Eitel et al., 2013), nested hierarchies (Nuthall, 1999; Gibson and McKay, 2001; Maxim, 2006), and "learning ladders" or "stepping stones" (O'Connor, 1999; Yugandhar, 2012). Since 2015, geography education researchers have considered learning progressions, or geo-progressions, for selected aspects of geographic knowledge, including maps, geospatial technology, spatial thinking, and place (Huynh, Solem, and Bednarz, 2015; Solem, Huynh, and Boehm, 2015; Larsen and Harrington, Jr., 2018a, 2018b).

Learning progression research is not just an important topic for geography educators, but for the discipline of geography. In geographic thinking, learning progression research is not paradigm-shifting, but paradigm-affirming. Humanistic geographers in the 1970s attended to the topic of progression in geographic understanding, drawing from phenomenological perspectives to evaluate how learners encounter their environment and how these experiences factor into their sense of place (see R. Hart, 1979; Tuan, 1977). Geographers continue to ask complex questions of contemporary pedagogy and consider educational systems as a useful base for building theories in human geography (Thiem, 2009). Learners and their distinctive lifeworlds become the subjects of geographic inquiry, rather than banal objects being herded through the educational system (Holloway et al., 2010; Nguyen, Cohen, and Huff, 2017). 
The inherent geographic nature of learning has yet to be fully realized and appreciated in learning progression research. Applying the learning progression approach can improve geography education insofar as the research method can be properly utilized, provided that geographers and education research specialists can discern which concepts to track (e.g., place, region, and synthesis, or humanenvironment thinking) and how to track the learning of these geographic identities in humans. Gersmehl and Gersmehl (2007) used advancement in brain research to identify eight concepts associated with thinking about conditions and connections that could/should be included in learning progression research. Progress is also needed on identifying the key concepts associated with advancing learning for the humanenvironment identity within geography.

\section{The Dynamics of Paradigms}

Paradigms and learning progressions have at least one thing in common: few people truly understand them and can identify when they occur. Nonetheless, many consider them important. A scientific paradigm, in Thomas Kuhn's (1962) sense, refers to a commonly accepted approach that many within the global scientific community view as appropriate to advancing 'big picture' knowledge. Paradigms are advantageous because they free up intellectual energy to move away from theory building and allow practitioners to embark on the unexplored areas within a subset of a discipline. In the traditional take on paradigms, a 'crisis' occurs when scholars discover a new way of seeing, one that compels the community to call the old paradigm into question. A revolution happens when the old paradigm is no longer viewed as the appropriate mindset for advancing the field. It takes a lot to reach a paradigm shift, and the transition is rarely easy.

Paradigm conceptualization has expanded to dozens of definitions and types. Three dominant categories exist and are arranged hierarchically: (1) meta-paradigms represent the global, 'big picture' outlook, (2) sociological paradigms denote significant scientific advancements, and (3) construct paradigms signify a classic text, method, or research instrument (Harvey and Holly, 1981). This paper deals primarily with construct paradigms. In geography's historiography, a number of construct paradigms have developed including environmental determinism, possibilism, exceptionalism, landscape morphology, and spatial organization (Abler, Adams, and Gould, 1971; Harvey and Holly, 1981; Unwin, 1992). Two or more construct paradigms can exist in the same discipline, either in competition or in co-existence with one another. Furthermore, paradigms typically contain four components: (1) exemplars (i.e., one or multiple major publications), (2) a key term that best represents the paradigm, (3) a theoretical foundation, and (4) a preferred or dominant set of methods (see Hartshorne, 1939; Harvey and Holly, 1981).

It can be hazardous to compare the structure of scientific paradigms to what is happening in education. Regardless, similarities exist. Contemporary thinking in education for K-12 students compares with the paradigm of normal science in the sense that education consists of a 'megaconstruct' - a vast hierarchy of ideas, activities, research, organizations, and overarching concepts (Abler, Adams, and Gould, 1971). 
Constructivist thinking in K-12 education, for example, represents one salient idea within a hierarchy. The constructivist megaconstruct also tends to prioritize math, science, and reading over subfields like the social sciences and geography education.

\section{Learning Progressions as Paradigm-Affirming}

In the educational megaconstruct, learning progression research falls under the constructivist paradigm. Pioneered by Jean Piaget and Lev Vygotsky, constructivism theorizes that knowledge is built upon and influenced by an individual's values and culture, as well as the ability to 'learn how to learn' (Gibson and McKay, 2001; Maxim, 2006; see also Paley, 2007; NAS, 2018). Constructivism can be separated into two subgroups, or exemplars, of thought: (1) cognitive constructivism and (2) social constructivism. Cognitive constructivism emphasizes the development of the brain in relation to learning, culture, and experience. Social constructivism stresses the value of the child's complex encounters with the classroom environment, family, ethnicity, and community (Gibson and McKay, 2001). In writing about ideas and relationships in constructivist learning, Stevens and colleagues (2014, p. 40) identify "definable levels" of consistency "across multiple knowledge domains." Learning progression research can advance progress within cognitive and social constructivist exemplars by mapping/identifying the development of key concepts at various levels among diverse student populations.

It would be a mistake for professional geographers to believe that learning progressions only have implications for K-12 educators. Learning progression research relates to a fundamental sense of what it means for a student to acquire a distinctive worldview, navigate their milieu (or social environment), and be a human living in the world. In geographic thought, learning progressions embody Paul Vidal de la Blache's and Lucien Febvre's paradigm of possibilism, that people learn from and adapt to their environment through complex daily interactions with nature, social relations, and meanings (Harvey and Holly, 1981; Unwin, 1992; Sack, 1997; Catling, 2006; Martin, 2015). Possibilism emphasizes human agency and exists in sharp contrast to the causeand-effect thinking of environmental determinism. Possibilism was an important antecedent to humanistic geography which includes an emphasis on "the thought and action of human beings and their ability to exert some independent control over their own destinies" (Cloke et al., 1991, p. 65). Humanistic geography's goals are to 1) use humility and empathy to explore what it means to be human and 2) apply that understanding to better inform people's interactions with places (Relph, 1981). Yi Fu Tuan (1977) notes that children's geographical horizons can expand as they grow. Learning becomes both an individual and collective process of discovery and sensemaking, a process that happens within and among places. Discovering and reconceptualizing the terrae incognitae of the world can lead to a progression in geographic understanding (Wright, 1947).

The capacity for place discovery is central to the possibilist paradigm, and connection to place has informed how scholars approach geographic and environmental learning (Tuan, 1974, 1977). In this human and cultural sense, the possibilist paradigm in geography aligns with the constructivist paradigm in education. The learning 
progression research approach blends these two paradigms. Learning builds with the construction of knowledge based on the accumulation of previous experiences, and those experiences have a strong place component. Thus, learning progression research has the potential to establish deeper connections between education and geographic thought. Two questions exist: which geographic concepts to track and how to track them.

\section{Learning Progressions-Which Concepts to Track}

First, learning progression research is only as effective as the concepts that track growth in student awareness. For learning progression research to advance, geographers need to help education researchers track geographic concepts that will improve a student's ability to navigate their career and civic life - a priority for national curriculum products like the C3 Framework (NCSS, 2013). The 'spatial conditions and connections' thought constructs from Gersmehl and Gersmehl (2007), which include 'place', provide a good starting point. But, in a world of accelerating global change, ocean and atmospheric warming, and biodiversity loss (Rockström et al., 2009), it also makes sense to explore learning progressions that document how students come to understand the importance of human impacts, globalization, synthesis, connecting the local with the global, and human-environment thinking.

Place, region, and synthesis. The concepts of place and region can help students think about the synergistic ideas being advocated by scientists, such as the whole being greater than the sum of the parts, synthesis, complexity, and consilience (Gober, 2000; Wilson, 1998; Watson, 2016). Places are dynamic, meaningful locales of Earth systems, human activities, and coupled nature and human interactions (Wilbanks and Kates, 1999; Gruenewald, 2003). Regions are collections of places with similar characteristics. Together, place and region represent intellectual devices for interpreting the complex arrangement of phenomena as a meaningful whole (Mugerauer, 1981; Seamon, 2018). The Next Generation Science Standards advocate for concepts that crosscut various scientific and engineering processes, such as patterns; systems and system models; energy and matter; structure and function; and stability and change (NGSS Lead States, 2013). While these crosscutting scientific concepts are important, they lack a robust geographic context and a grounding in how socio-environmental phenomena function in places and regions. Learning progression research for place and region could add a local connection to student understanding of synthesis thinking (Larsen and Harrington, Jr., 2018b).

Geography's human-environment identity. From the mid-twentieth century to present, geographers and geography educators have tended to emphasize aspects of the spatial-chorological identity-space, place, and region-more than the humanenvironment identity (Turner, 2002). While geographers were thinking spatially, the planet was experiencing a Great Acceleration in the pace of global change. In the twenty-first century, the Anthropocene concept (i.e., the 'Age of Humans') has increased in use as a transdisciplinary 'big idea' for discussing aspects of the planetaryscale transformations happening in the human-environment relationship. The idea of an Anthropocene was first proposed as a geologic epoch which attempts to establish a time 
in geologic history when humans irreversibly changed the Earth system (Crutzen and Stoermer, 2000). The Anthropocene concept has since expanded beyond the Earth sciences and has been addressed by scholars in literary history, biology, geography, and philosophy, among others (Steffen et al., 2011; Menely and Taylor, 2017; Bjornerud, 2018).

Geographers have been investigating topics addressing the human-environment relationship well before the informal geologic epoch's conception in 2000 (Crutzen and Stoermer, 2000). French geographer Élisée Reclus ([1866] 2013, p. 110) foreshadowed a day when "the effects of human labor will extend to every point on the surface of the earth." According to Murphy (2018, p. 90), "of the traditional disciplines, geography today is the one that arguably is most centrally concerned with looking at the interrelations between natural and human processes on the Earth's surface." In the historiography of geography, one can identify Marsh's (1864) Man and nature, Thomas's (1956) Man's role in changing the face of the Earth, Glacken's (1967) Traces on the Rhodian Shore, and Turner et al.'s (1990) The Earth as transformed by human action. Additionally, Harlan Barrows's (1923) human ecology and Carl Sauer's (1925) morphology of landscape are identified as early twentieth-century human-environment approaches. Sauer's historical and cultural approach to understanding humanenvironment connections is a precursor to a contemporary emphasis on traditional ecological knowledge (TEK). TEK scholars seek to challenge the "Westward, forwardlooking gaze of progress" and demonstrate the broader relevance of indigenous interactions with and perceptions of the environment (Wildcat, 2009, p. 113). Given this scholarly tradition within geography, educators should expand learning progression research beyond the spatial-chorological identity to consider how students progress in learning about aspects of the human-environment identity (Larsen and Harrington, Jr., 2018b).

\section{Learning Progressions-How to Track}

Learning progressions are tracked according a series of waypoints that mark students' advancement from beginner (lower anchor) to advanced (upper anchor) understandings (Gunckel, Mohan et al., 2012). Mapping threshold moments in student understanding can inform how learners pass through elusive intermediate sequences, also known as the "messy middle" (Krajcik, 2011; Huynh and Gotwals, 2015). Once a specific aspect of geographic knowledge is selected and justified for research on advancing growth in student knowledge, the second question is how to develop a learning progression.

\section{Using Discourses to Track Learning}

When examining complex socio-environmental issues, education researchers have developed a variety of methods to assess student progress. Of particular importance is the discourse approach, which allows for researchers to map student learning by how effectively students can articulate their thinking about a concept or phenomenon. How effectively students speak or write about an issue can provide a useful reference for what they know; a student begins with primary discourse-what they already know 
about a topic - and gains secondary discourses through educational intervention (Gunckel, Mohan et al., 2012).

Discourse progressions have deep roots in human-environment thinking. One progression includes transitioning beyond the dualism of a 'first and second nature'. First voiced by Cicero in $45 \mathrm{BCE}$, first nature involves the environment as separate from people, while second nature refers to the state in which humans transform the environment (for better or worse) for societal purposes (see Glacken, 1967). Alternative discourses promote more synergistic, integrated conceptions of how humans and the environment interrelate ( $c f$. McKibben, 1989; Botkin, 1990; Rockström et al., 2009). In early modern geography, Alexander von Humboldt (1849, p. 367) claimed that: language is a part and parcel of the history of the development of mind" and that the phenomenon emerges through a dialectic among individuals engaging with one another and with the natural environment.

By virtue of their ability to communicate, humans are permitted to "comprehend nature, to lift the veil that shrouds her phenomena, and, as it were, submit the results of observation to the test of reason and of intellect" (Humboldt, 1849, p. 3). Learning progression research affords the opportunity to trace a holistic transformation in geographic thinking.

Open-ended, longitudinal assessments and semi-structured interviews have allowed for the development of learning progerssions for scientific argumentation (Berland and McNeill, 2010), issues of water quantity and quality in socio-ecological systems (Gunckel, Covitt et al., 2012), climate change and sea level rise (Breslyn et al., 2016), energy's role in carbon transformations within sociological systems (Jin and Anderson, 2012), and ecosystem complexity (Hokayem and Gotwals, 2016). A geographer entering the realm of learning progression research would encounter a field already addressing how students comprehend human-environment issues at local, regional, and global scales.

Addressing informal learning. Learning progression research to-date risks being preoccupied with cognitive abilities in the confines of the classroom or formal field trip environment. This reduces the learning experience to the information that is supposed to be consumed in school. Oriented from a possibilist construct paradigm, geography education researchers have a chance to apply and expand geographic ideas to improve learning progression research. For example, geography education's regular use of qualitative and mixed-methods research may improve upon how learning progressions are investigated and developed within K-12 education (see Lidstone and Stoltman, 2008). Innumerable geographic learning interventions exist outside the classroom. The pioneering work of environmental psychologist Roger Barker (1968; see also Barker and Wright, 1954), the geographer and author of Children's experience of place Roger Hart (1979), and others (e.g., Louv, 2008) point to the need for more holistic, wholechild thinking. A metaphorical 'Garden of Peace' - that mental state where clarity and enlightened understandings of today's meta-issues reside (Wadley, 2008) - may not materialize within the cloister of the school setting. Students have the capacity to learn 
geography from their community (i.e., a local museum) and not just from the classroom teacher.

As societies become increasingly mobile, students possess diverse forms of informal geographic knowledge that can be leveraged in the classroom (Smith, 2007; Larsen and Harrington, Jr., 2016). Acquiring disciplinary knowledge should be coupled with students' attitudes toward the subject matter. Student aspirations are powerful drivers of learning (C.S. Hart, 2013; Zipin et al., 2015; McCulloch, 2017; Sheldrake, Mujtaba, and Reiss, 2017). Aspirations are complex socio-cultural phenomena that vary in length, within and among individuals, and geographic contexts (Somerville, 2013; Khattab, 2014; Holmberg et al., 2018). Under the combination of constructivist educational and possibilist geography paradigms, learning progressions are more likely to succeed when the methods are place-based and give voice to the students' aspirations and ideas of their surroundings (see Catling, 2005, 2006). The research should discern how a child's geographical horizon expands from local to global as they build on past activity and acquire new experiences and learning interventions.

Learning progression research assessing acquisition of geographic knowledge also needs to account for the discipline's discontinuity and inconsistency in formal K-12 education. Within the United States, geographic ideas are relevant at all grades, but students do not have the good fortune to have a steady sequence of classes in geography in K-12 and higher education. Unfortunately, formal instruction in geography is taught sporadically and in various formats throughout grade levels in each state. Geographic education scholars criticize how contemporary educational contexts deprive students of capabilities that will be of value in careers and civic life (Solem, Lambert, and Tani, 2013; Lambert, Solem, and Tani, 2015). The literature on critical geographies of education has stressed the impacts of socio-cultural barriers to students' learning abilities (Lim and Barton, 2010; Nguyen, Cohen, and Huff, 2017; Pini et al., 2017).

Learning progression research offers one way to collect and analyse data that address the accumulation of geographic knowledge over time. There is a need for in-depth, wide-angle studies on the development of spatial and human-environment thinking during the human lifespan. From a possibilist mindset, opportunities abound for students to engage the world autobiographically, reflecting upon their own interactions with the environment and how these encounters affected them and their community. For example, did a transformation occur when a middle school student from Houston, Texas discovered that class discussion about social consequences of hurricanes could be witnessed first-hand within her own community? Did a rural Iowan third grader acquire a more complex understanding of agricultural systems after talking with his grandparents about how farming practices have changed through time? How could a high schooler from Flint, Michigan comprehend the vexed concept of environmental justice by examining the legacy of uneven treatment of municipal water services in the city?

Learning progression research addressing geographic concepts may benefit from long-range tracking of the lifelong learner from preschool, through school, to career. To assist with that task, we may learn much about getting to geography's 'upper anchors' 
when we ask professional geographers about both the complex geographic skills and knowledge they employ on a daily basis and when they 'got it.' For example, did scouting or military service help individuals recognize the power of map reading and spatial thinking? Did travel as a member of the military or on a family vacation to visit national parks help with recognition of differences in physical and cultural environments? This approach, where geographers are asked to think back, would rightly blur the barriers between formal and informal education. The tactic would also recontextualize how geographic learning is perceived, enabled, and parameterized.

\section{Coda}

'Progress' is an imprecise term that can take on a multitude of competing definitions. From a general standpoint, Reclus ([1905] 2013, 208) described progress as "the general improvement of humanity throughout history," emphasizing the transformation of people's awareness about their relationship with others and nature. In advancing a more sustainable future, learning progression researchers must not simply track student progress in comprehending a topic for its own sake. They ought to account for how knowledge gained can be applied to enhance student agency to solve various socio-environmental issues (Peeters, Dirix, and Sterckx, 2013; Pelenc et al., 2013; Sen, 2013). Possibilism depends upon this notion of human-environment understanding and capability. Moreover, human capability adds a pragmatic dimension to constructivism's 'learning how to learn.'

Geographers can draw from constructivist and possibilist paradigms to develop learning progressions for human-environment issues in the Anthropocene. Constructivism and possibilism complement each other and provide a theoretical basis from which to examine the paths people take to make sense of topics like environmental hazards, risk, vulnerability, and resilience; land use and land cover (LULC) change; political ecology; agroecology; resource management; food and health geographies; and big ideas in environmental policy and management (see Zimmerer, 2010). Furthermore, the transformative concept of the Anthropocene suggests a greater need for students to cultivate a sense of timefulness, a deeper and clearer understanding of the past and its relationship with the present and future (Bjornerud, 2018). Those realizations can be charted by exploring relationships among disciplinary content, levels of discourse, student aspirations, geographic contexts, and types of educational interventions.

The idea of a constructivist learning progression is not revolutionary. Learning progression research is a key method to understand growth in student thinking that can combine the educational constructivist and geography possibilist paradigms. Geography advances as a discipline when its researchers consider alternative perspectives on how humans acquire and mature in their geographic knowledge, skills, and perspectives.

\section{Acknowledgement}

The authors wish to thank Dr. Lisa Millsaps for comments on earlier versions of this paper. 


\section{References}

Abler, R., Adams, J.S., and Gould, P. (1971). Spatial organization: The geographer's view of the world. Englewood Cliffs, NJ: Prentice-Hall.

Barker, R.G. (1968). Ecological psychology: Concepts and methods for studying the environment of human behavior. Stanford, CA: Stanford University Press.

Barker, R.G., and Wright, H.F. (1954). Midwest and its children: The psychological ecology of an American town. White Plains, NY: Row, Peterson and Company.

Barrows, H.H. (1923). Geography as human ecology. Annals of the American Association of Geographers, 13(1), 1-14.

Berland, L.K., and McNeill, K.L. (2010). A learning progression for scientific argumentation: Understanding student work and designing supportive instructional contexts. Science Education, 94(5), 765-793.

Bjornerud, M. (2018). Timefulness: How thinking like a geologist can help save the world. Princeton, NJ: Princeton University Press.

Black, P., Wilson, M., and Yao, S.Y. (2011). Road maps for learning: A guide to the navigation of learning progressions. Measurement, 9(2), 71-123.

Botkin, D.B. (1990). Discordant harmonies: A new ecology for the twenty-first century. New York: Oxford University Press.

Breslyn, W., McGinnis, J.R., McDonald, R.C., and Hestness, E. (2016). Developing a learning progression for sea level rise, a major impact of climate change. Journal of Research in Science Teaching, 53(10), 1471-1499.

Catling, S. (2005). Seeking younger children's 'voices' in geographical education research. International Research in Geographical and Environmental Education, 14(4), 297-304.

Catling, S. (2006). What do five-year-olds know of the world?-Geographical understanding and play in young children's early learning. Geography, 91(1), 55-74.

Cloke, P., Philo, C., and Sadler, D. (1991). Approaching human geography. London: Chapman.

Crutzen, P.J., and Stoermer, E.F. (2000). The Anthropocene. Global Change Newsletter, 41, $17-$ 18.

Eitel, A., Scheiter, K., Schuler, A., and Nystrom, M. (2013). How a picture facilitates the process of learning from text: Evidence for scaffolding. Learning and Instruction, 28, 4863.

Foster, E.K., and Hund, A.M. (2012). The impact of scaffolding and overhearing on young children's use of the spatial terms between and middle. Journal of Child Language, 39(2), 338-364.

Furtak, E.M., Morrison, D., and Kroog, H. (2014). Investigating the link between learning progressions and classroom assessment. Science Education, 98(4), 640-673.

Gersmehl, P.J., and Gersmehl, C.A. (2007). Spatial thinking by young children: Neurologic evidence for early development and 'educability.' Journal of Geography, 106(5), 181191.

Gibson, S., and McKay, R. (2001). What constructivist theory and brain research may offer social studies. Canadian National Social Studies Journal, 35(4). Retrieved March 19, 2019, from https://canadian-social-studies-journal.educ.ualberta.ca/content/articles-2000- 
2010\#ARconstructionist_theory45.

Glacken, C. (1967). Traces on the Rhodian Shore. Berkeley: University of California Press.

Gober, P. (2000). In Search of Synthesis. Annals of the Association of American Geographers, 90(1), 1-11.

Gruenewald, D.A. (2003). Foundations of place: A multidisciplinary framework for placeconscious education. American Educational Research Journal, 40(3), 619-654.

Gunckel, K.L., Covitt, B.A., Salinas, I., and Anderson, C. W. (2012). A learning progression for water in socio-ecological systems. Journal of Research in Science Teaching, 49(7), 843868.

Gunckel, K.L., Mohan, L., Covitt, B.A., and Anderson, C.W. (2012). Addressing challenges in developing learning progressions for environmental science literacy. In A.C. Alonzo and A.W. Gotwals (Eds.), Learning progressions in science: Current challenges and future directions, (pp. 27-36). Rotterdam, The Netherlands: Sense Publishers.

Hammer, D., and Sikorski, T. (2015). Implications of complexity for research on learning progressions. Science Education, 99(3), 424-431.

Hart, C.S. (2013). Aspirations, education, and social justice: Applying Sen and Bourdieu. London: Continuum International.

Hart, R. (1979). Children's experience of place. New York, NY: Irvington.

Hartshorne, R. (1939). The nature of geography: A critical survey of current thought in the light of the past. Annals of the American Association of Geographers, 29 (3-4), 413-658.

Harvey, M.E., and Holly, B.P. (1981). Paradigm, philosophy, and geographic thought. In M.E. Harvey and B.P. Holly (Eds.), Themes in geographic thought (pp. 11-37). London: St. Martin's Press.

Hokayem, H., and Gotwals, A.W. (2016). Early elementary students' understanding of complex ecosystems: A learning progression approach. Journal of Research in Science Teaching, 53(10), 1524-1545.

Holloway, S.L., Hubbard, P., Jöns, H., and Pimlott-Wilson, H. (2010). Geographies of education and the significance of children, youth, and families. Progress in Human Geography, 34(5), 583-600.

Holmberg, L., Kalalahti, M., Vargo, J., Kivirauma, J., Mäkeläb, M., Saarinen, M., Zacheus, T., and Jahnukainen, M. (2018). Educational trajectories of immigrant-origin youths in Finland: A mixed methods analysis. Journal of Education and Work, 31(7-8), 563-578.

Huynh, N.T., and Gotwals, A.W. (2015). What are learning progressions? In M. Solem, N.T. Huynh, and R.G. Boehm (Eds.), Learning progressions for maps, geospatial technology, and spatial thinking: A research handbook (pp. 1-8). Washington, D.C.: Association of American Geographers.

Huynh, N.T., Solem, M., and Bednarz, S.W. (2015). A road map for learning progressions research in geography. Journal of Geography, 114(2), 69-79.

Jin, H., and Anderson, C.W. (2012). A learning progression for energy in socio-ecological systems. Journal of Research in Science Teaching, 49(9), 1149-1180.

Khattab, N. (2014). How and when do educational aspirations, expectations, and achievement align? Sociological Research Online, 19(4), 6. DOI: 10.5153/sro.3508. 
Krajcik, J. (2011). Learning progressions provide road maps for the development and validity of assessments and curriculum materials. Measurement, 9(2-3), 155-158.

Kuhn, T.S. (1962). The structure of scientific revolutions. Chicago, IL: University of Chicago Press.

Lambert, D., Solem, M., and Tani, S. (2015). Achieving human potential through geography education: A capabilities approach to curriculum making in schools. Annals of the American Association of Geographers, 105(4), 723-735.

Larsen, T., and Harrington, J., Jr. (2016). Mental maps and a community-based sense of place: A case study among Kansas third graders. Research in Geographic Education, 18(2), 86111.

Larsen, T., and Harrington, J., Jr. (2017). Place, learning progressions, and transformative geographic education. Research in Geographic Education, 19(2), 66-79.

Larsen, T., and Harrington, J., Jr. (2018a). Developing a learning progression for place. Journal of Geography, 117(3), 100-118.

Larsen, T., and Harrington, J., Jr. (2018b). Place, learning progressions, and progress. Journal of Geography, 117(3), 133-136.

Lidstone, J., and Stoltman, J. (2008). Research paradigms and reflections in geographical and environmental education. International Research in Geographical and Environmental Education, 17(3), 195-198.

Lim, M., and Barton, A.C. (2010). Exploring insideness in urban children's sense of place. Journal of Environmental Psychology, 30(3), 328-337.

Louv, R. (2008). Last child in the woods: Saving our children from Nature Deficit Disorder. Chapel Hill, NC: Algonquin Books of Chapel Hill.

Marsh, G.P. ([1864] 2003). Man and nature: Or, physical geography as modified by human action. Seattle, WA: University of Washington Press.

Martin, G.J. (2015). American geography and geographers: Toward geographical science. Oxford: Oxford University Press.

Maxim, G.W. (2006). Dynamic social studies for constructivist classrooms, 8th ed. Upper Saddle River, New Jersey: Pearson.

McCulloch, A. (2017). Educational aspirations trajectories in England. British Journal of Educational Studies, 65(1), 69-85.

McKibben, B. (1989). The end of nature. New York: Random House.

Menely, T., and Taylor, J.O. (Eds). (2017). Anthropocene reading: Literary history in geologic times. University Park, PA: Pennsylvania State University Press.

Mugerauer, R. (1981). Concerning regional geography as a hermeneutical discipline. Geographische Zeitschrift, 69(1), 57-67.

National Academies of Science (NAS). (2007). Taking science to school: Learning and teaching science in grades $K-8$. Washington, D.C.: National Academies Press.

National Academies of Science (NAS). (2018). How people learn II: Learners, contexts, and cultures. Washington, DC: National Academies Press.

National Council for the Social Studies (NCSS). (2013). The College, Career, and Civic Life 
Larsen, B., T.; Harrington, J. (2019). Learning Progressions, Paradigms, and Geographic Thinking in......

(C3) Framework for Social Studies State Standards: Guidance for enhancing the rigor of K-12 civics, economics, geography, and history. Silver Spring, MD: NCSS.

NGSS Lead States. (2013). Next Generation Science Standards: For states, by states. Washington, DC: National Academies Press.

Nguyen, N., Cohen, D., and Huff, A. (2017). Catching the bus: A call for critical geographies of education. Geography Compass, 11(8). DOI: 10.1111/gec3.12323.

Nuthall, G. (1999). The way students learn: Acquiring knowledge from an integrated science and social studies unit. The Elementary School Journal, 99(4), 303-341.

O'Connor, R.E. (1999). Teachers learning ladders to literacy. Learning Disabilities Research and Practice, 14(4), 203-214.

Paley, V.G. (2007). On listening to what the children say. Harvard Educational Review, 77(2), 152-163.

Peeters, W., Dirix, D., and Sterckx, S. (2013). Putting sustainability into sustainable human development. Journal of Human Development and Capabilities, 14(1), 58-76.

Pelenc, J., Lompo, M.K., Ballet, J., and Dubois, J. (2013). Sustainable human development and the capability approach: Integrating environment, responsibility and collective agency. Journal of Human Development and Capabilities, 14(1), 77-94.

Pini, B., Gulson, K.N., Krafti, P., and Dufty-Jones, R. (2017). Critical geographies of education: An introduction. Geographical Research, 55(1), 13-17.

Plumert, J.M., and Nichols-Whitehead, P. (1996). Parental scaffolding of young children's spatial communication. Developmental Psychology, 32(3), 523-532.

Reclus, É. ([1866] 2013). The feeling for nature in modern society. In J. Clark and C. Martin (Eds.), Anarchy, geography, modernity: Selected writings of Élisée Reclus (pp. 103-112). Oakland: PM.

Reclus, É. ([1905] 2013). Progress. In J. Clark and C. Martin (Eds.), Anarchy, geography, modernity: Selected writings of Élisée Reclus (pp. 208-233). Oakland: PM.

Reiser, B.J. (2004). Scaffolding complex learning: The mechanisms of structuring and problematizing student work. The Journal of the Learning Sciences, 13(3), 273-304.

Relph, E. (1981). Rational landscapes and humanistic geography. London, NY: Croom Helm.

Rockström, J., Steffen, W., Noone, K., Persson, Å. Chapin, F.S., III, Lambin, E.F., Lenton, T.M., Scheffer, M., Folke, C., Schellnhuber, H., Nykvist, B., de Wit, C.A., Hughes, T., van der Leeuw, S., Rodhe, H., Sörlin, S., Snyder, P.K., Costanza, R., Svedin, U., Falkenmark, M., Karlberg, L., Corell, R.W., Fabry, V.J., Hansen, J., Walker, B., Liverman, D., Richardson, K., Crutzen, P., Foley, J. (2009). Planetary boundaries: Exploring the safe operating space for humanity. Ecology and Society, 14(2), 32. [online] URL: http://www.ecologyandsociety.org/vol14/iss2/art32/.

Sack, R.D. (1997). Homo geographicus. Baltimore, MD: Johns Hopkins University Press.

Sauer, C.O. (1925). The morphology of landscape. University of California Publications in Geography, 2(2), 19-53.

Seamon, D. (2018). Life takes place: Phenomenology, lifeworlds, and place making. New York: Routledge.

Sen, A. (2013). The ends and means of sustainability. Journal of Human Development and 
Capabilities, 14(1), 6-20.

Sheldrake, R., Mujtaba, T., and Reiss, M.J. (2017). Science teaching and students' attitudes and aspirations: The importance of conveying the applications and relevance of science. International Journal of Educational Research, 85, 167-183.

Smith, G.A. (2007). Place-based education: Breaking through the constraining regularities of public school. Environmental Education Research, 13(2), 189-207.

Solem, M., Huynh, N.T., and Boehm, R.G. (Eds). (2015). Learning progressions for maps, geospatial technology, and spatial thinking: A research handbook. Newcastle upon Tyne, UK: Cambridge Scholars Press.

Solem, M., Lambert, D., and Tani, S. (2013). Geocapabilities: Toward an international framework for researching the purposes and values of geography education. Review of International Geographical Education Online, 3(3), 214-229.

Somerville, M. (2013). The 'placetimemattering' of aspiration in the Blacktown Learning Community. Critical Studies in Education, 54(3), 231-244.

Steffen, W., Grinevald, J., Crutzen, P., and McNeill, J.R. (2011). The Anthropocene: Conceptual and historical perspectives. Philosophical Transactions: Mathematical, Physical and Engineering Sciences, 369(1938), 842-867.

Stevens, S., Gotwals, A.W., Jin, H., and Barrett, J. (2014). Learning progressions research planning and design. In M. Solem, N.T. Huynh, R. Boehm (Eds.), Learning progressions for maps, geospatial technology and spatial thinking: A research handbook (pp. 23-44). Washington, D.C.: Association of American Geographers.

Thiem, C.H. (2009). Thinking through education: The geographies of contemporary educational restructuring. Progress in Human Geography, 33(2), 154-173.

Thomas, W.L., Jr., (Ed.). (1956). Man's role in changing the face of the Earth. Chicago, IL: University of Chicago Press.

Tuan, Y. (1974). Topophilia: A study of environmental perception, attitudes, and values. Englewood Cliffs, NJ: Prentice-Hall.

Tuan, Y. (1977). Space and place: The perspective of experience. Minneapolis, MN: University of Minnesota Press.

Turner, B.L., II. (2002). Contested identities: Human-environment geography and disciplinary implications in a restructuring academy. Annals of the American Association of Geographers, 92(1), 52-74.

Turner, B.L., II, Clark, W.C., Kates, R.W., Richards, J.F., Mathews, J.T., and Meyer, W.B. (Eds.). (1990). The Earth as transformed by human action: Global change and regional changes in the biosphere over the past 300 years. Cambridge: Cambridge University Press, with Clark University.

Unwin, T. (1992). The place of geography. Harlow: Longman Scientific and Technical.

Von Humboldt, A. (1849). Cosmos: A sketch of a physical description of the university, trans. E.C. Otte. London: Harrison and Son.

Wadley, D. (2008). The Garden of Peace. Annals of the American Association of Geographers, 98(3), 650-685.

Watson, P. (2016). Convergence: The idea at the heart of science. New York, NY: Simon and 
Schuster.

Wilbanks, T., and Kates, R.W. (1999). Global change in local places: How scale matters. Climatic Change, 43(3), 601-628.

Wildcat, D.R. (2009). Red alert! Saving the planet with indigenous knowledge. Golden, CO: Fulcrum.

Wilson, E.O. (1998). Consilience: The unity of knowledge. New York, NY: Vintage.

Wright, J.K. (1947). Terrae incognitae: The place of the imagination in geography. Annals of the American Association of Geographers, 31(1), 1-15.

Yugandhar, K. (2012). An insight into incentives of open-ended activities in English language learning. International Journal of English and Education, 1(1), 20-28.

Zimmerer, K.S. (2010). Retrospective on nature-society geography: Tracing trajectories (19112010) and reflecting on translations. Annals of the American Association of Geographers, 100(5), 1076-1094.

Zipin, L., Sellar, S., Brennan, M., and Gale, T. (2015). Educating for futures in marginalized regions: A sociological framework for rethinking and researching aspirations. Educational Philosophy and Theory, 47(3), 227-246.

\section{Biographical Statements}

Thomas Barclay LARSEN serves as a Senior Research Associate of the Gilbert M. Grosvenor Center for Geographic Education and Lecturer for the Texas State University Department of Geography, San Marcos, Texas, USA. His research interests include humanenvironment relationships, the Anthropocene, geographic thought, geography education, learning progressions, and powerful disciplinary knowledge.

John HARRINGTON, Jr. is an Independent Scholar and Professor Emeritus in geography from Kansas State University, Manhattan, Kansas, USA. He served as coordinator for the Kansas Geographic Alliance from 2007-2018. His research interests include climatology, human dimensions of global change, GIScience, applied geography, geographic thought, and geography education. 